\title{
Specifics of diagnosing young children and counseling their families
}

\author{
Olesya Yugova $^{1 *}$, Oksana Prikhodko $^{1}$, Elena Rykova ${ }^{1}$, and Sviatlana Feklistova ${ }^{2}$ \\ ${ }^{1}$ Moscow City University, Institute of Special Education and Psychology, Moscow, Russia \\ ${ }^{2}$ Belarusian State Pedagogical University named after Maxim Tank, Institute of Inclusive Education, \\ Minsk, Belarus
}

\begin{abstract}
The article justifies the need for early diagnosis of mental and physical developmental disorders in young children. The article describes the basic principles, approaches, and features of the psychological and pedagogical diagnosis of the development deviations in infants and young children. Recommendations for the tools and methods of the diagnosis of young children are given, based on the need to assess certain skills and functions. The main factors that influence the mental and physical state of young children are characterized. The article gives recommendations for the duration of the diagnostic procedure and basic requirements for the premises for conducting a psychological and pedagogical diagnosis of the development of children. The main methods and techniques, used in the diagnosis of young children, are presented. The authors of the article identify the problem of negative impacts of the social environment on the formation of a complex system of sensory receptor connections and the mental state of a child. The article describes the influence of the birth of a child with developmental disabilities on the family and the features of the emotional response to the diagnosis or medical report. The objectives and the characteristics of counseling parents of children with disabilities are given along with the content of the initial stages of counseling and support. The relevance of using online counseling for parents is also identified. The article describes the organizational model of work with the "child-parent" system and characterizes the main pedagogical conditions, which are the most favorable for the development of a child.
\end{abstract}

Keywords: psychological and pedagogical counseling of families, children with disabilities, early diagnosis of developmental disorders.

\section{Introduction}

The need for comprehensive early pedagogical correction support for young children is emphasized by many researchers in the field of special pedagogy and psychology. Scholars have proven that early correctional and developmental influence creates an opportunity to correct and prevent secondary development deviations in children (E.A. Ekzhanova, N.N. Malofeev, G.A. Mishina, R.Zh. Mukhamedrakhimov, O.G. Prikhodko, Yu.A. Razenkova, E.A. Strebeleva, L.I. Filchikova, N.D. Shmatko, and others).

* Corresponding author: kor.ped@inbox.ru 
The beginning of the development of diagnostic tools for the psychological and pedagogical diagnosis of young children was marked by A.A. Venger, G.L. Vygodskaya, E.I. Leonhard (1972), S.D. Zabramnaya (1971), V.I. Lubovsky (1971), and others. The scholars made a special contribution to the differential diagnosis of developmental disorders, pointing out the need for early diagnosis of primary developmental disorders. Today, the content and methods of differential diagnosis of young children are identified (N.L. Galiguzova, T.V. Ermolova, M.I. Lisina, S.Yu. Meshcheryakova, E.O. Smirnova, E.A. Strebeleva, and others).

\section{Methods}

Comprehensive diagnosis of the development of young children makes it possible to reveal the age characteristics of children, their levels of mental and physical development, and development deviations [1]. Besides, the mental and physical development diagnosis of young children is dynamic and allows creating an environment, which gradually becomes more and more complex following the child's changing state and capabilities [2].

To conduct a psychological and pedagogical diagnosis of young children, it is necessary to consider several principles: a comprehensive approach; the principle of integral systemic examination of a child; the principle of dynamic observation of a child and qualitative analysis of the obtained data; the principle of age-related features of a child's development [3]. Today, psychological and pedagogical development diagnosis includes an integral examination of a child, taking into account the individual and age characteristics of development [4].

The main methods and techniques used in the diagnosis of young children include observation, conversation, questioning, collection of anamnestic data, psychological and pedagogical experiments, research methods using special equipment, etc. [5]. Differential diagnosis of developmental disorders in young children is personality-oriented. Sociopsychological analysis of a child's living conditions and development, as well as the analysis of parent-child relations, is a prerequisite for its implementation. It is also worth emphasizing that the presence of the parents (legal representatives) of the child during the examination procedure is necessary.

It is extremely important to consider the instability of the behavior of small children, the arbitrariness of their mental processes, and dependence on several factors. Young children need to alternate mental and physical activity due to the weakness of their nervous processes. An essential rule of diagnostic examination is the naturalness of situations, an emotionally positive attitude of a child, and a satisfactory state of health. The premise, in which the diagnosis takes place, should be comfortable and attractive for a child, but not too bright and distracting. It is obligatory to establish emotional contact and a trusting attitude towards a specialist [6].

Young children's ability for voluntary attention just begins to form. Cognitive activity, which is especially pronounced at this age, encourages children to move and switch attention to new objects, while monotony tires them. In this regard, the duration of the diagnosis should not exceed 10-15 minutes. The premise, where the diagnosis is carried out, should be ventilated before the beginning, and all dangerous items should be removed [7].

When choosing methodological tools for diagnosis, it is important to consider the fact that the priority for the cognitive development of young children is the enrichment of sensory experience and the formation of objective actions and thinking. Accordingly, it is advisable to use for assessment such objects and toys that reveal the features of various forms of perception, the level of formation of the main sensory receptors, the possibility of performing various actions with objects, and the level of development of visual thinking. Toys and pictures presented to young children must be safe, realistic, and attractive. At the same time, 
there are features of the organization of the environment conducive to learning for different categories of children with disabilities [8].

Numerous scholars in the field of psychology and pedagogy emphasize the importance of family education and the presence and active participation of parents for the full-fledged formation of a child's personality (Sh.A. Amonashvili, A.I. Herzen, P.F. Lesgaft, A.S. Makarenko, V.A. Sukhomlinsky, K.D. Ushinsky). The problem of negative impacts of the social environment is of particular importance in early childhood due to the immaturity of a child's brain.

The features and problems of the process of supporting the family of a child with disabilities are described in the works by A.I. Zakharov, O.A. Karabanova, I. Yu. Levchenko, I.I. Mamaichuk, E.M. Mastyukova, G.A. Mishina, A.G. Moskovkina, R. Zh. Mukhamedrakhimova, M.M. Semago, A.S. Spivakovskaya, E.A. Strebeleva, V.V. Tkacheva, E.G. Eidemiller, and others.

\section{Results}

Families with children with developmental disabilities are included in the category of vulnerable groups of the population and have significant difficulties in functioning as an institution of human socialization. Such families experience various problems: psychological, economic, and lack of information about possible educational, medical, and other services. They lose the ability to socially adapt and, in most cases, need the help of specialists to overcome this situation.

Wrong parenting models are often used in families with children with developmental disabilities. The birth of a child with problems in mental and physical development introduces qualitative changes at the psychological, social, and somatic levels and destructively affects all family subsystems. To overcome these changes, families with children with disabilities should be supported by specialists [9]. Difficulties associated with raising a child with special needs predetermine qualitative changes in the life of the family, challenge the family, and lead to a crisis.

The need for comprehensive early support is also caused by the high compensatory capabilities of the central nervous system and all mental functions of infants and young children. At the same time, according to the all-Russian monitoring of the activities of psychological, medical, and pedagogical commissions, only $8 \%$ of all requests are from families raising infants and young children. This is one of the most urgent tasks of the diagnosis, counseling, and support of children with disabilities and their families at the present stage [10].

As a rule, families with premature infants, low-birth-weight infants, and children who received treatment from a neonatal intensive care unit or hospital turn to early intervention services as soon as possible. The greatest anxiety and the most frequent requests for help from parents are associated with a delay in the child's speech development and less often with other higher mental functions, behavior, and the motor system [11].

Comprehensive psychological and pedagogical diagnosis of a child's development helps to identify the level of the actual state and further development and determine the disorder and individual characteristics. Such diagnosis is one of the most important components of counseling, but not the only one [12]. According to normative documents, parental counseling is aimed at meeting the needs of both the child and family in development, mental health, adaptation, and successful socialization [13].

Counseling of parents of children with developmental disabilities involves solving the following tasks: assistance in establishing positive relationships in the family; selection of an adequate style of family education; convincing parents of the child's potential; reducing emotional tension in the family; helping parents constructively resolve negative and 
traumatic situations. Psychological and pedagogical counseling covers both already existing and possible difficulties and focuses on the prevention of the development deviations in young children and the intrafamily and social relations and interactions. It can be one-time or long-term, individual or group. Online consulting is becoming more and more widespread in the modern world.

\section{Discussion}

During counseling, the following rules should be observed. The attitude towards parents should be tactful and respectful; information must be accurately formulated and understandable. It is necessary to avoid both negative assessments of the activities of other specialists, the parents, and the child and, on the contrary, the exaggeration of the child's abilities. Improving the effectiveness of counseling of a child and family is possible if there is an adequate overview of the child's characteristics among all participants of the educational process and if the specifics of the social situation of the child's development are taken into account.

A detailed examination of families and the specifics of parent-child relations is of primary importance for providing targeted support to children and ensuring effective interaction between all family members. When designing psychological and pedagogical counseling, it is necessary to consider the features of parental attitudes, their possible fears and anxieties. The main objective of counseling is to determine the main pedagogical conditions, which are the most favorable for the development of a child [14].

At the initial stage of the acquaintance with a family, to be more precise, during conversation and questioning, the specialist receives information about the members of the family, child-parent relations, parental views, and approaches to upbringing and identifies their requests. An effective method of studying families is observation (including the process of diagnosis), during which many features of the relationship and communication between adults and children are revealed. The features of parent-child relations are most fully revealed in joint activities [15]. It is also advisable to use modern technology and video materials from family archives to study the stages of a child's development.

It is important to bear in mind that the family of a child with problems in mental and physical development is in a state of continuous stress. Sometimes, after receiving the results of a diagnosis or medical report, they deny it and cannot understand the situation; they cannot accept it and respond adequately according to the child's needs. Emotional adaptation takes some time and the help of support specialists is needed [16].

\section{Conclusion}

The process of correctional work is transformed within the family-centered approach. The organization of work with the "child-parents" system creates conditions for the active involvement of parents in the rehabilitation process and increases their psychological and pedagogical competence. Support specialists act as consultants and form competencies necessary to help children.

\section{References}

1. T.V. Nikolaeva, Kompleksnoe psikhologo-pedagogicheskoe obsledovanie rebenka rannego vozrasta s narushennym slukhom [Comprehensive psychological and pedagogical diagnosis of young children with hearing disabilities] (Ekzamen, Moscow, 2006) 
2. E.V. Samsonova, Model organizatsii inklyuzivnogo obrazovatelnogo protsessa $v$ detskom sadu [The organizational model of an inclusive educational process in preschool], in Collection of works Inklyuzivnoe obrazovanie. Metodicheskie rekomendatsii po organizatsii inklyuzivnogo obrazovatelnogo protsessa $\mathrm{v}$ detskom sadu [Inclusive education. Recommended methods for organizing an inclusive educational process in preschool], 4, 3-42 (Tsentr "Shkolnaya kniga", Moscow, 2010)

3. E.V. Sheremeteva, Preduprezhdenie otklonenii rechevogo razvitiya u detei rannego vozrasta [Prevention of speech development deviations of young children] (Natsionalnyi knizhnyi tsentr, Moscow, 2012)

4. E.A. Strebeleva, G.A. Mishina, Psikhologo-pedagogicheskaya diagnostika narushenii razvitiya detei rannego i doshkolnogo vozrasta [Psychological and pedagogical diagnosis of developmental disorders of young children and preschoolers] (Mozaikasintez, Moscow, 2016)

5. O.V. Eletskaya, A.A. Tarakanova, Psikhologo-pedagogicheskaya diagnostika razvitiya lits s ogranichennymi vozmozhnostyami zdorovya [Psychological and pedagogical diagnosis of the development of people with disabilities] (Flinta, Moscow, 2020)

6. E.O. Smirnova, L.N. Galiguzova, T.V. Ermolova, S.Y. Meshcheryakova, Diagnostika psikhicheskogo razvitiya rebenka. Mladencheskii i rannii vozrast [Children's mental development diagnosis. Infants and young children] (Mozaika-sintez, Moscow, 2013)

7. O.G. Prikhodko, Predmetno-razvivayushchaya obrazovatelnaya sreda dlya detei pervykh let zhizni s ogranichennymi vozmozhnostyami zdorovya [Environment conducive to learning for young children with disabilities], in Rannee i doshkolnoe obrazovanie v sisteme nepreryvnogo soprovozhdeniya detei s ogranichennymi vozmozhnostyami zdorovya. Sbornik nauchnykh statei po materialam nauchnoprakticheskoi konferentsi [Collection of scientific articles based on the materials of the scientific and practical conference "Early and preschool education in the system of continuous support of children with disabilities"], 22-23 March 2017, Moscow, Russia (2017)

8. O.V. Yugova, E.A. Rykova, A.V. Mironova, Sovremennaya nauka: aktualnye problemy teorii i praktiki. Humanities series, 5, 157-161 (2020). https://doi.org/10.37882/2223-2982.2020.05.38

9. I.Y. Levchenko, V.V. Tkacheva, Psikhologicheskaya pomoshch seme, vospityvayushchei rebenka s otkloneniyami v razvitii [Psychological assistance to a family raising a child with developmental disorders] (Prosveshchenie, Moscow, 2008)

10. L.Y. Vakorina, O.G. Prikhodko, O.V. Yugova, RUDN Journal of Sociology, 19(4), 814-824 (2019). https://doi.org/10.22363/2313-2272-2019-19-4-814-824

11. A.V. Brodskaya, Vospitanie i obuchenie detei s narusheniyami razvitiya, 2, 55-61 (2017)

12. O.G. Prikhodko, O.V. Yugova, Spetsialnoe obrazovanie, 2(42), 85-93 (2016)

13. I.A. Filatova, E.V. Karakulova, Psikhologo-pedagogicheskoe konsultirovanie roditelei i spetsialistov psikhologo-pedagogicheskogo soprovozhdeniya detei rannego vozrasta, detei-invalidov i detei s OVZ v Sverdlovskoi oblasti [Psychological and pedagogical counseling for parents and specialists in psychological and pedagogical support of young children and children with disabilities in the Sverdlovsk region] (Ural State Pedagogical University, Ekaterinburg, 2019)

14. V.V. Tkacheva, Semya rebenka s ogranichennymi vozmozhnostyami zdorovya: diagnostika i konsultirovanie [The family of a child with disabilities: diagnosis and counseling] (VLADOS, Moscow, 2014) 
15. V.I. Seliverstov, O.A. Denisova, L.M. Kobrina (Eds.), Spetsialnaya semeinaya pedagogika. Semeinoe vospitanie detei s otkloneniyami v razvitii [Special family pedagogy. Family upbringing of children with developmental disabilities] (VLADOS, Moscow, 2009)

16. A.G. Moskovkina, Semeinoe vospitanie detei s razlichnymi narusheniyami v razvitii [Family education of children with various developmental disorders] (VLADOS, Moscow, 2015) 